\title{
Genetic variability of Colletotrichum sublineolum through ISSR markers
}

\author{
Variabilidade genética de Colletotrichum sublineolum através de marcadores ISSR \\ Variabilidad genética de Colletotrichum sublineolum através de marcadores ISSR
}

Received: 01/20/2021 | Reviewed: 01/23/2021 |Accept: 02/05/2021 | Published: 02/10/2021

Thallita Santos Guimarães

ORCID: https://orcid.org/0000-0002-7952-0644 State University of Mato Grosso, Brazil

E-mail: thallita_guimaraes@hotmail.com

Marco Antonio Aparecido Barelli

ORCID: https://orcid.org/0000-0002-6385-6733 State University of Mato Grosso, Brazil

E-mail: mbarelli@unemat.br

Carla Lima Corrêa

ORCID: https://orcid.org/0000-0001-8549-8415 State University of Mato Grosso, Brazil

E-mail: correa.carla@yahoo.com.br

Valvenarg Pereira da Silva

ORCID: https://orcid.org/0000-0001-8450-3016 State University of Mato Grosso, Brazil

E-mail: silvabiologo@hotmail.com

Alex Junior Sandol Floriano

ORCID: https://orcid.org/0000-0003-1781-7247 State University of Mato Grosso, Brazil E-mail: alex_florianovb@hotmail.com

Nilo Leal Sander

ORCID: https://orcid.org/0000-0001-9856-6819 State University of Mato Grosso, Brazil

E-mail: nilosander@gmail.com

Aline Vidor Melão Duarte

ORCID: https://orcid.org/0000-0001-5621-7127 State University of Mato Grosso, Brazil

E-mail: melao.a.v.bio@gmail.com

Bruno Wagner Zago

ORCID: https://orcid.org/0000-0001-6985-7828 State University of Mato Grosso, Brazil E-mail: brunowzago@hotmail.com

Jackson Lauro Borges Ribeiro

ORCID: https://orcid.org/0000-0002-2808-3798 State University of Mato Grosso, Brazil

E-mail: jeck.borges@hotmail.com

Flávio Dessaune Tardin

ORCID: https://orcid.org/0000-0001-5755-2728 Brazilian Agricultural Research Corporation - Embrapa Maize \& Sorghum, Brazil

E-mail: flavio.tardin@embrapa.br

Dagma Dionísia da Silva

ORCID: https://orcid.org/0000-0002-4037-3739

Brazilian Agricultural Research Corporation - Embrapa Maize \& Sorghum, Brazil

E-mail: dagma.silva@embrapa.br

\begin{abstract}
The occurrence of diseases is a limiting factor in the development of sorghum crop. Among the diseases that causes losses in sorghum production, anthracnose is the main and most severe, mainly by the genetic variability of the pathogen. In this context, the aim of this study was to evaluate the genetic variability of Colletotrichum sublineolum isolates. DNA were extracted from 56 monosporic isolates of C. sublineolum using a DNA extraction kit, and to perform the analysis of genetic diversity of the isolates were used ISSR primers. After amplification, it was determined the polymorphic information content (PIC), allelic frequency, UPGMA and Tocher clustering analyzes and, using software Structure, the genetic structure. According to the descriptive analysis of the genetic variability of C. Sublineolum isolates, primer AP1 presented the higher value of polymorphic information content (PIC). The higher allelic frequency was observed in loci 06, 09, 10, and 24, and the lowest in locus 02 . As for the clustering method, it was observed a tendency of grouping $C$. sublineolum isolates according the geographic origin and, in addition to demonstrating the genetic variability between the $C$. sublineolum isolates, it was observed the occurrence of introgression among the isolates.
\end{abstract}


Keywords: Sorghum bicolor (L.) Moench; Anthracnose; Molecular markes.

\section{Resumo}

A ocorrência de doenças é um fator limitante no desenvolvimento da cultura do sorgo. Dentre as doenças que causam prejuízos na produção de sorgo, a antracnose é a principal e mais severa, principalmente pela variabilidade genética do patógeno. Nesse contexto, o objetivo deste estudo foi avaliar a variabilidade genética de isolados de Colletotrichum sublineolum. O DNA foi extraído de 56 isolados monospóricos de C. sublineolum por meio de um kit de extração de DNA, e para realizar a análise da diversidade genética dos isolados foram utilizados os primers ISSR. Após a amplificação, determinou-se o conteúdo de informação polimórfica (PIC), frequência alélica, análises de agrupamento UPGMA e Tocher e, por meio do software Structure, a estrutura genética. De acordo com a análise descritiva da variabilidade genética dos isolados de C. Sublineolum, o primer AP1 apresentou o maior valor de conteúdo de informação polimórfica (PIC). A maior frequência alélica foi observada nos locos $06,09,10$ e 24 , e a menor no locus 02. Quanto ao método de agrupamento, observou-se uma tendência de agrupar os isolados de $C$. sublineolum de acordo com a origem geográfica e, além de demonstrando a variabilidade genética entre os isolados de C. sublineolum, foi observada a ocorrência de introgressão entre os isolados.

Palavras-chave: Sorghum bicolor (L.) Moench; Antracnose; Marcadores moleculares.

\section{Resumen}

La aparición de enfermedades es un factor limitante en el desarrollo del cultivo de sorgo. Entre las enfermedades que ocasionan pérdidas en la producción de sorgo, la antracnosis es la principal y más grave, principalmente por la variabilidad genética del patógeno. En este contexto, el objetivo de este estudio fue evaluar la variabilidad genética de aislados de Colletotrichum sublineolum. Se extrajo ADN de 56 aislados monospóricos de $C$. sublineolum utilizando un kit de extracción de ADN, y para realizar el análisis de diversidad genética de los aislados se utilizaron cebadores ISSR. Después de la amplificación, se determinó el contenido de información polimórfica (PIC), la frecuencia alélica, los análisis de agrupamiento de UPGMA y Tocher y, utilizando el software Structure, la estructura genética. Según el análisis descriptivo de la variabilidad genética de los aislados de C. Sublineolum, el cebador AP1 presentó el mayor valor de contenido de información polimórfica (PIC). La mayor frecuencia alélica se observó en los loci 06, 09, 10 y 24, y la menor en el locus 02. En cuanto al método de agrupamiento, se observó una tendencia a agrupar los aislados de C. sublineolum según el origen geográfico y, además de demostrando la variabilidad genética entre los aislados de C. sublineolum, se observó la ocurrencia de introgresión entre los aislados.

Palabras clave: Sorghum bicolor (L.) Moench; Antracnosis; Marcadores moleculares.

\section{Introduction}

Sorghum bicolor (L.) Moench is the world's $5^{\text {th }}$ most important cereal in relation to yield potential and planted area, being used primarily in animal feed, nutrition and biofuel. The crop has expanded in Brazil, thus making the country one of the $10^{\text {th }}$ biggest producers of sorghum in the world (Conab, 2015; Conab, 2016).

Sorghum is a $\mathrm{C} 4$ plant, presenting biomass production capacity and stands out in relation to its energy potential when compared to other crops, mainly for having features that make it attractive to the market, as low implantation and production costs, short cycle, fully mechanizable, high calorific value in boilers and great tolerance of drought, which make it possible to be cultivated in different edaphoclimatic conditions (Castro, 2014).

There are several phytosanitary issues that affect sorghum crop, among them are the diseases, which can cause significant losses, depending on the susceptibility of the cultivated variety to the pathogen and favorable environmental conditions to its occurrence and dissemination (Silva et al., 2008). Among the sorghum diseases, anthracnose is the main and the most devastating, affecting the whole plant, causing significant losses in all types of sorghum, being upper to $80 \%$ of the grain production and more than 50\% of the forage (Casela et al., 2000; Pereira et al., 2011).

The causal agent of anthracnose, Colletotrichum sublineolum (P. Hen, Kabat \& Bulbak), belongs to the order Melanconiales, which includes asexual fungi that produces spores (conidia) in reproductive structures called acervuli (Costa et al., 2003). The pathogenic agent variability in Brazilian conditions is one of the limiting factors of developing resistant cultivars (Casela \& Frederiksen, 1994; Panizzi \& Fernandes, 1997).

The Colletotrichum species can be differentiated by traditional methods, as conidia shape and dimension, fungi colony colour and mycelial growth rate, among others morphologic and cultural characteristics (Freeman et al., 1998). However, this 
characterization is not enough, due to the great phenotypic diversity and instability of these characters, arising from the environment (Andrade et al., 2007). Due to the importance of these characteristics for the characterization of the fungus species, it is necessary complementary techniques that increases the opportunity of improvement and safety in its identification.

Molecular techniques are a complementary tool for the populational study of $C$. sublineolum, because they allow an accurate analysis of the pathogen genetic variability, being capable to detect mutational changes in coding regions of a limited number of genes that express enzymes, making it easier and faster the identifications of the species and isolates of pathogenic fungi.

Among the markers based on microsatellite repetition, ISSR (Inter-Simple Sequence Repeat) are widely used for the study of genetic variability of $C$. sublineolum. ISSR are dominant marker that amplify between microsatellites sequences, using a single primer, composed by a repeated sequence and anchored, with two or four nucleotides in one end (Zietkiewicz et al., 1994; Caixeta et al., 2009). According to Perumal et al. (2008), this technique can be used to elaborate strategies of improvement, considering the resistance to local population of the pathogen and to verify the incidence of new virulent races.

Genetic variability studies of the anthracnose etiological agent produce information that provides subsidies for genetic improvement programs of sorghum. In this regard, this study aimed to analyze the genetic variability of Colletotrichum sublineolum isolates sampled in Cáceres-MT and compare these with those sampled in Sete Lagoas, Minas Gerais.

\section{Methodology}

The research was conducted at the Laboratory of Genetic Resources \& Biotechnology (LGR\&B), linked to the Agronomy Department, State University of Mato Grosso - UNEMAT. We made use of 56 isolates of Colletotrichum sublineolum - 31 sampled at the experimental field of the UNEMAT-Cáceres-MT and 25 from Sete Lagoas-MG.

Subsequent obtaining the $C$. sublineolum monosporic isolates, the extraction of the DNA was conducted using the Wizard $^{\circledR}$ Genomic DNA Purification kit (Promega, Madison, WI), according to the manufacturer's recommendations. For the amplification of the genomic DNA, 20 ISSR loci primers were tested and of these, 11 were selected to represent the genetic variability of the $C$. sublineolum isolates (Table 1).

Table 1. Sequence of bases of 11 selected ISSR molecular markers, fragment size generated by PCR and polymorphic information content (PIC) representing the genetic variability of 56 Colletotrichum sublineolum isolates, Cáceres-MT, 2017.

\begin{tabular}{ccc}
\hline Primers (Sequência 5'3') & Tamanho do fragmento & PIC \\
\hline AP1 & $2340-400$ & 0,47 \\
AP3 & 1000 & 0,03 \\
AP4 & $1027-700$ & 0,33 \\
(GTG)6 & $2294-894$ & 0,24 \\
(TG)8GT & $1557-700$ & 0,46 \\
CAC & $2600-1000$ & 0,33 \\
(AAG)6 & $878-458$ & 0,22 \\
UBC 810 & $1872-518$ & 0,14 \\
UBC 817 & $3000-862$ & 0,31 \\
UBC 850 & $1094-754$ & 0,35 \\
UBC 881 & $2085-820$ & 0,36 \\
Max. - Min. & $3000-400$ & - \\
Média & - & 0,29 \\
\hline
\end{tabular}


PCR amplification reactions were prepared in a final volume of $20 \mu \mathrm{L}$, using $2,0 \mu \mathrm{L}$ of $10 \mathrm{x}$ buffer solution, $1,6 \mu \mathrm{L}$ of $2 \mathrm{mM} \mathrm{MgCl}_{2}, 4,0 \mu \mathrm{L}$ of 2,0 mM dNTP's, $0,2 \mu \mathrm{L}$ of Taq DNA polymerase, 3,0 $\mu \mathrm{L}$ of $2 \mathrm{mM}$ of primer, 1,0 $\mu \mathrm{L}$ of formamide and 2,0 $\mu \mathrm{L}$ of genomic DNA.

Reaction amplification was performed on an Aeris Thermal Cycler, according thermal cycle programme: initial denaturation of $3 \mathrm{~min}$ at $94{ }^{\circ} \mathrm{C}$; followed by 35 amplification cycles of $30 \mathrm{~s}$ at $94{ }^{\circ} \mathrm{C}, 30 \mathrm{~s}$ at melting temperature, $30 \mathrm{~s}$ at $72{ }^{\circ} \mathrm{C}$ and final extension of $5 \mathrm{~min}$ at $72{ }^{\circ} \mathrm{C}$., keeping at $4{ }^{\circ} \mathrm{C}$ until samples were taken out of the Thermal Cycler.

To determine the size of the amplified fragment, PCR products were electrophoresed in 1.5\% agarose $1 \mathrm{x}$ TBE and visualized and photographed under UV light (Photodocumentator DNR Bio Imaging System - MicroBIS); 100 pb DNA Ladder marker were used as comparison and the images were processed using GelQuant Pro software.

After the reaction amplification, molecular analyses were performed. Primarily was determined the Polymorphic Information Content (PIC) of each ISSR primer using Power Marker V.3.25 software. Also were determined allelic frequency of all molecular markers locus in the C. sublineolum isolates, using GenAlEx v.6.5 softaware (Genetic Analysis in Excel).

STRUCTURE software, based on Bayesian statistics was used to infer isolates genetic structure and determine the most probable number of groups (k) among the C. sublineolum isolates. Therefore, was performed 20 iterations per K, with a burn-in length of 200.000 steps with 500.000 Monte Carlo Simulations of Markov Chains. In order to determine the most probable $\mathrm{K}$ in relation to those proposed, we used the criteria described by Pritchard \& Wen (2004) e Evanno et al. (2005).

Employing the matrix generated by Jaccard's coefficient, a dendrogram was constructed by using the unweighted pair group method with arithmetic average (UPGMA) in R software. The cophenetic correlation coefficient was determined to ensure the adjustment between the matrix and the dendrogram constructed by the UPGMA clustering method. Tocher method was employed based on the dissimilarity matrix using Genes software (Cruz, 2013).

\section{Results}

According to the results, among the 11 selected primers, it was possible to verify the presence of 42 bands, all polymorphic. The number of band amplified per primer varied between 01 (AP3) and 08 (AP1) and AP1 showed the highest number of amplified bands, with 08 polymorphic bands, and also was the most informative in demonstrating the genetic variability of $C$. sublineolum isolates (Table 1).

In Table 1 are presented fragment sizes ranging from 400 to $3000 \mathrm{bp}$, and the polymorphic information content (PIC) ranging from 0.03 to 0.47 , with an average of 0.29 .

In Figure 1, it is demonstrated the allelic frequency in each locus, showing how common an allele is in the study population. According to the results, loci 06, 09, 10 and 24 showed the highest allelic frequencies, with $98 \%$ of frequency, being present in 55 C. sublineolum isolates. The lowest allelic frequency was recorded in the locus 02 , with $5 \%$ of allelic frequency, being present in 03 isolates. Generally, it was observed differences in allelic frequencies in the loci of $C$. sublineolum isolates, indicating the existence of variability among them. 
Figure 1. Allelic frequency of 42 ISSR loci in 56 monosporic isolates of Colletotrichum sublineolum, Cáceres-MT, 2017.

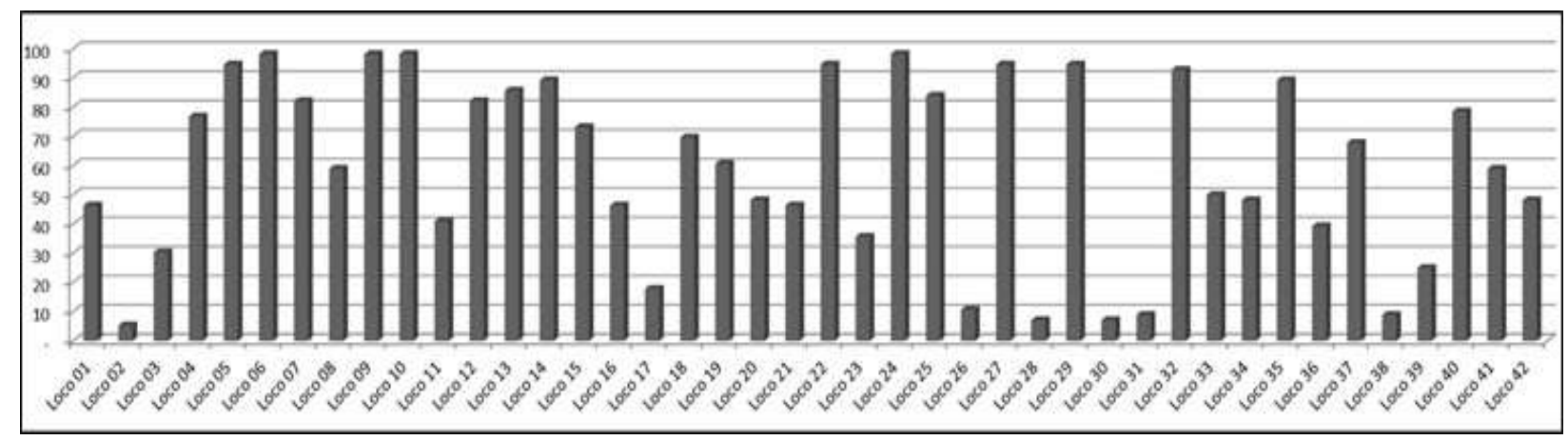

Source: Authors.

Structure software, based on Bayesian statistics, inferred on the populational structure of C. sublineolum isolates through the definition of number of groups $(\Delta \mathrm{k})$, and the best $\mathrm{K}$ for the $C$. sublineolum isolates, that is, the best clustering that fit the data was the representation of three groups $(\mathrm{k}=3)$ (Figure 2).

Figure 2. Graphical analysis of the number of groups for the monosporic isolates of Colletotrichum sublineolum according to the 11 ISSR markers information, by the means of Structure software, Cáceres-MT, 2017.

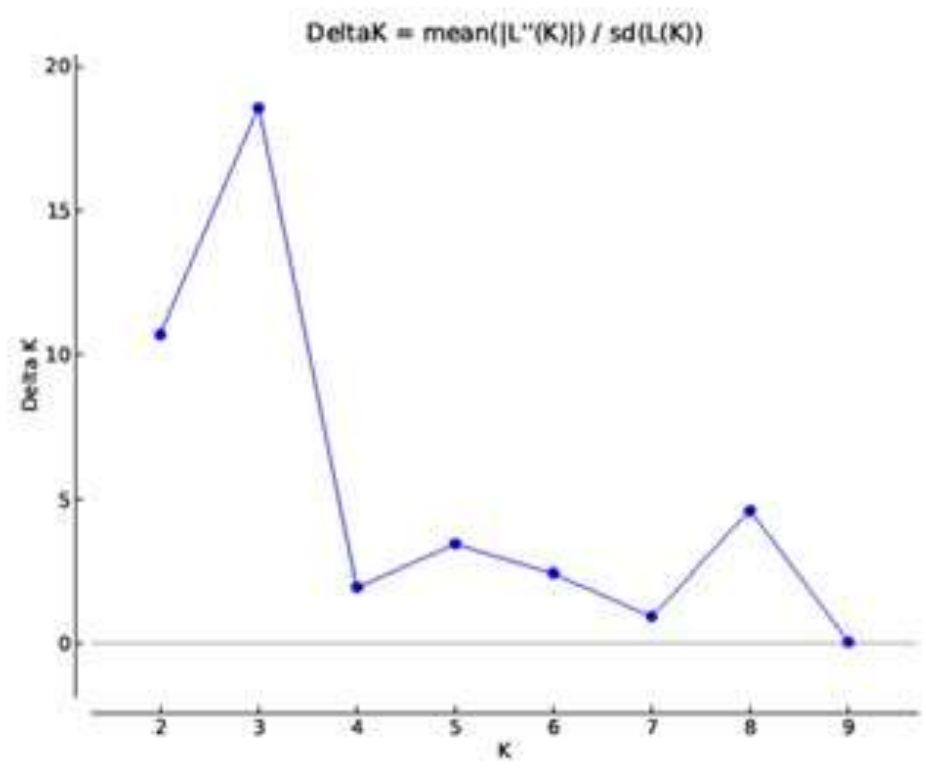

Source: Authors.

In Structure clustering (Figure 3), it was possible to observe the structuring of the C. sublineolum isolates in the three groups, wherein, group I (red) comprised of 21 isolates, of which 17 are from Cáceres-MT. Group II (green) comprised of 20 isolates, of which 16 are from Sete Lagoas-MG. Group III (blue) comprised of 15 isolates, of which 10 from Cáceres-MT. 
Figure 3. Clustering representation of 56 monosporic isolates of Colletotrichum sublineolum according to molecular data of 11 ISSRs using Structure software. The isolates are represented by vertical bars with coloration according to the group to which they belong: group I - red, group II - green and group III blue. (three groups, K=3), Cáceres-MT, 2017.

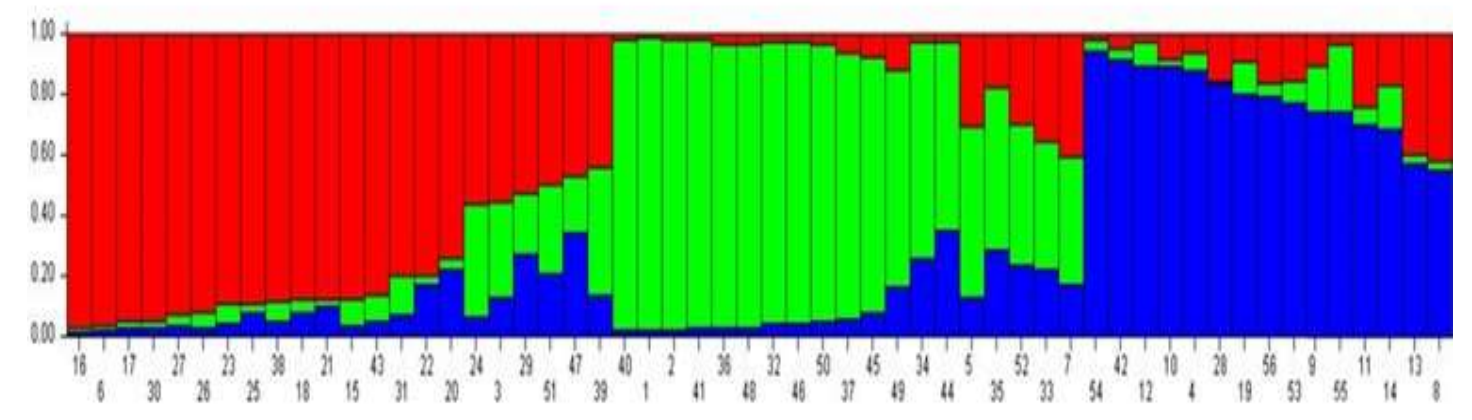

Source: Authors.

It is possible to observe that the $C$. sublineolum isolates from Sete Lagoas-MT tended to be clustered in one group and the isolates from Cáceres-MT in other two groups. The distribution of $C$. sublineolum isolates throughout the dendrogram by UPGMA method (Figure 4) present the formation of six groups, showing that the isolates have genetic variability.

Figure 4. Representative dendrogram of the genetic clustering analysis of 56 Colletotrichum sublineolum isolates, obtained by UPGMA clustering method using R software, Cáceres-MT, 2017.

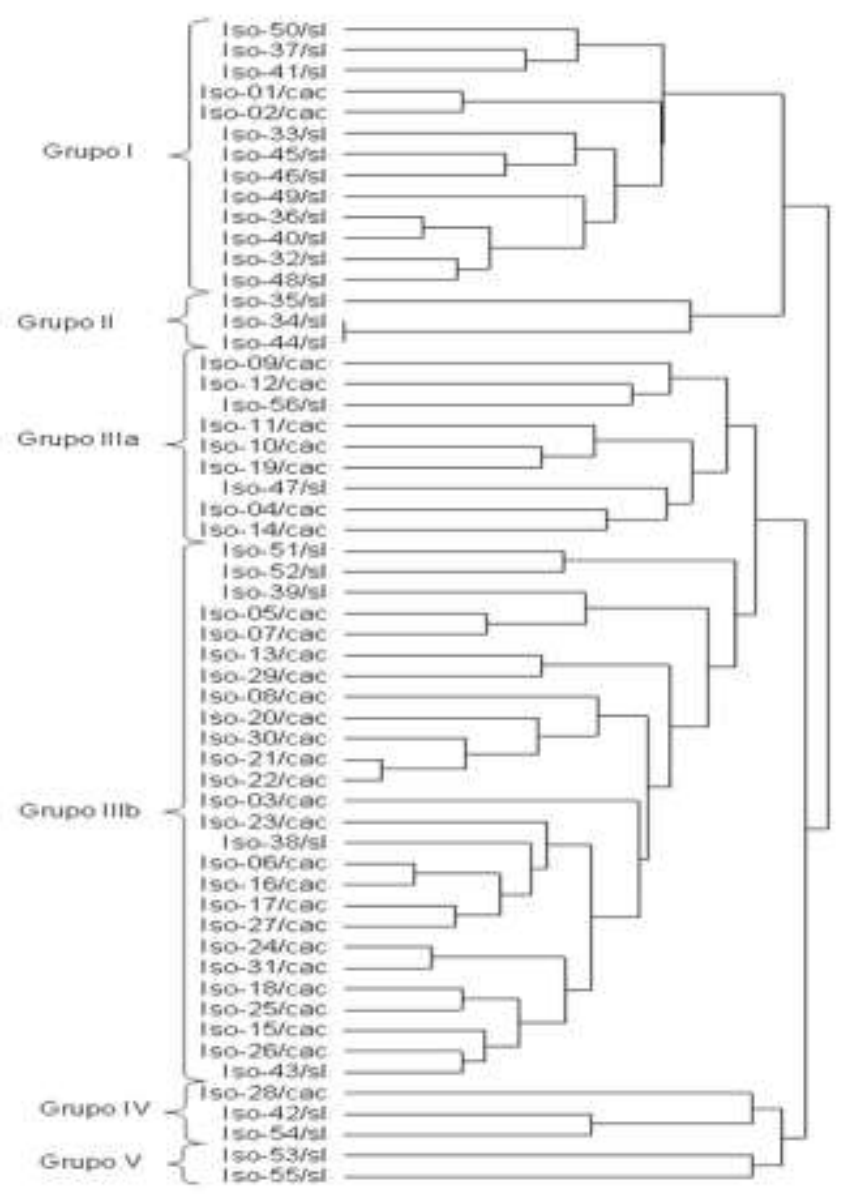

Source: Authors. 
Group I is formed by 13 isolates, of which 11 are from Sete Lagoas and two isolates from Cáceres-MT. Group II and $\mathrm{V}$ are formed by three isolates each from the same place of origin, all from Sete Lagoas-MG. Still in group II, it is possible to observe that isolates Iso-34/sl and Iso-44/sl does not present genetic difference, being the most similar when compared to the other isolates in this study, suggesting that these isolates possibly belong to the same race.

Group III comprised the greatest number of isolates (thirty-five), for this reason, group III was subdivide in IIIa and IIIb, wherein Group IIIa is composed of nine isolates, of which seven isolates are from Cáceres-MT and group IIIb is composed of twenty-six isolates, wherein the shorter genetic distance was observed between isolates Iso-21/cac and Iso-22/cac.

The cophenetic correlation coefficient (CCC) applied in the UPGMA clustering method showed a value of 0.70 between the distances obtained in the dissimilarity matrix and the cophenetic matrix.

The clustering by Tocher method made possible the formation of eight groups (Table 2) with the isolates evaluated. The formation of different groups evidences the variability present among the C. sublineolum isolates, indicating the most similar and the most divergent. In this clustering method, the groups are formed so that there is homogeneity within the group and heterogeneity between the groups, that is, groups individuals maintaining the criteria that intra-group distances are always smaller than inter-group distances (Cruz \& Regazzi, 2001).

Table 2. Clustering representation generated by Tocher method based on the dissimilarity between 56 monosporic isolates of Colletotrichum sublineolum, Cáceres-MT, 2017.

\begin{tabular}{ccc}
\hline Grupos & Isolados & \% de isolados \\
\hline I & Iso-34/sl, Iso-44/sl, Iso-36/sl, Iso-40/sl, Iso-48/sl, Iso-32/sl, Iso-50/sl, Iso-41/sl, & 16,07 \\
II & Iso-37/sl & 41,07 \\
& 20/cac, Iso-17/cac, Iso-38/sl, Iso-27/cac, Iso-26/cac, Iso-15/cac, Iso-18/cac, Iso- & \\
& 25/cac, Iso-43/sl, Iso-31/cac, Iso-24/cac, Iso-13/cac, Iso-39/sl, Iso-03/cac, Iso- & \\
III & 51/sl, Iso-08/cac, Iso-56/sl & 12,50 \\
IV & Iso-01/cac, Iso-02/cac, Iso-46/sl, Iso-45/sl, Iso-33/sl, Iso-49/sl, Iso-05/cac & 14,28 \\
& Iso-10/cac, Iso-19/cac, Iso-11/cac, Iso-04/cac, Iso-12/cac, Iso-47/sl, Iso-14/cac, & \\
V & Iso-09/cac & 5,35 \\
VI & Iso-42/sl, Iso-54/sl, Iso-28/cac & 3,57 \\
VII & Iso-29/cac e Iso-52/sl & 3,57 \\
VIII & Iso-53/sl e Iso-55/sl & 3,57 \\
\hline TOTAL & Iso-07/cac e Iso-35/sl & $\mathbf{1 0 0 , 0}$ \\
\hline
\end{tabular}

Source: Authors.

The clustering formation by Tocher method occurred in a similar way to the clustering by UPGMA hierarchic method, although not identical. Group I is composed by 09 isolates (16.07\%), all from Sete Lagoas-MG.

Group II is composed by the majority of isolates (gathering $41.07 \%$ of isolates, from Cáceres-MT and Sete LagosMG). Group III comprised of 07 isolates (12.5\%). Group IV comprised of 08 C. sublineolum isolates, of which only one (Iso47/sl) are from Sete Lagoas-MG, maintaining the same grouping that occurred in UPGMA method (group IIIa). There has been a tendency of clustering according to the isolates' place of origin. 
Group V is composed of three isolates (5.35\%), just as it occurred in UPGMA method. Groups VI, VII and VIII comprised of only two (3.57\%) isolates each.

\section{Discussion}

Similar results regarding the number of polymorphic bands found in this study were also observed by Parreira et al. (2016) when evaluated the genetic variability of $C$. graminicola using 15 ISSR primers, detected the presence of 66 polymorphic bands.

The polymorphic information content (PIC), according classification proposed by Botstein et al. (1980), molecular markers with PIC values higher than 0.50 are considered very informative, values ranging between 0.25 and 0.50 are averagely informative and values lower than 0.25 are little informative. Based on this classification, among the 11 primers used, seven were averagely informative, with PIC values above 0.25 (AP1, AP4, (TG) 8GT, CAC, UBC 817, UBC 850 and UBC 881), being the most informative for C. sublineolum. According to Boza et al. (2013), the higher the polymorphism (PIC), the better the identification of genetic diversity of the sample, thus, primers that show higher PIC values are more adequate to study genetic variability of $C$. sublineolum.

Structure analysis group individuals according to genetic differences, without prior identification of the individuals (Rossi et al., 2014). In this study, it was observed a tendency of clustering isolates according the geographic origin and most of the isolates do not have a homogenous structure within the group, that is, has different colours in the same bar in the bar plot, indicating genetic introgression between the three groups, once 38 of the 56 analyzed C. sublineolum isolates varies in each bar plot.

In this study, the presence of introgression is due possibly to the genetic variability between isolates, furthermore, the presence of introgression is important for further processes in genetic improvement programs, because, according to Abbott et al. (2013), the presence of introgression may be an important source of genetic variability in populations.

Cophenetic correlation coefficient value obtained through the results, demonstrate reliability in the relation between the dissimilarity matrix and the UPGMA dendrogram, once according to Rohlf (1970), CCC values higher than 0.70, reflect good agreement between the matrices and the dendrogram generated based on a data set. Furthermore, according to Cruz \& Carneiro (2003), the higher the CCC, the lower will be the distortion caused by the data clustering, corroborating with this study, in which the CCC was high and the distortion reached 3.96\%.

Results obtained by UPGMA method indicates that isolates from Cáceres/MT and Sete Lagoas/MG has genetic variability, since they were observed in different genetic groups, which makes difficult obtaining resistant plants. Therefore, it is important to know the genetic variability present between isolates of pathogen and the use of molecular techniques support the populational dynamic study of the pathogen (Parreira et al., 2010).

Variability between C. sublineolum isolates was also observed by Silva (2009) when evaluate the genetic variability between different $C$. sublineolum isolates from different parts of Brazil and observed the presence of variability between them.

Similar results were also observed by Santos et al. (2015) when evaluated genotypic and pathogenic diversity of Colletotrichum musae in the state of Pernambuco/Brasil using ISSR, and observed a tendency of clustering isolates from the same geographical location.

Although the majority of isolates from the same geographical locations tended to group together, some isolates geographically distant formed a genetic group. According to Cardwel et al. (1989), the pathogen can be disseminated long distances through infected seeds, which are source of inocula between producing areas. Perhaps, this may have contributed to the geographically distant isolates being genetically similar. 
According to the clustering made by UPGMA and Tocher method, it was observed that group II and V formed by UPGMA and group I formed by Tocher, comprised of isolates from Sete Lagoas, showing similarity between this isolates, cause according to Bertran et al. (2006), individuals contained in a same group indicates that they share greater genetic similarity. Group V formed by UPGMA and groups VI, VII, VIII formed by Tocher presented the lowest number of $C$. sublineolum isolates clustered-only two, and as described by Benitez et al. (2011), groups formed by only one or phew individuals, indicates that these individuals are the most divergent in relation to the other.

The similarity between both clustering methods (UPGMA and Tocher) demonstrates that the methods are complementary to each other, and assist in the indication of the most divergent isolates. Besides that, the agreement between UPGMA and Tocher clustering methods in the differentiation of the most divergent and the most similar isolates, provides subsides for more safe inferences about the variability between the isolates evaluated.

\section{Final Considerations}

The isolates of $C$. sublineolum presented genetic variability and the clustering methods used demonstrated that the isolates tended to organize themselves according to their local of origin. Besides presenting genetic variability, there are indications of gene introgression in the different genetic groups of $C$. sublineolum isolates analyzed, as this information are important for genetic improvement programs of sorghum.

\section{Acknowledgments}

This study was partially financed by State Research Support Foundation of Mato Grosso (FAPEMAT), National Council for Scientific Development and Technological (CNPq) and Coordination for the Improvement of Level Personnel Superior - Brazil (CAPES) - Finance Code 001.

\section{References}

Abbott, R., et al. (2013). Journal of Evolutionary Biology, 26(2), 229-246. https://doi.org/10.1111/j.1420-9101.2012.02599.x.

Andrade, E. M. Uesugi, C. H. Ueno, B. \& Ferreira, M. A. S. V. (2007). Caracterização morfocultural e molecular de isolados de Colletotrichum gloeosporioides patogênicos ao mamoeiro. Fitopatologia Brasileira, 32(1), 21-31. https://doi.org/10.1590/S0100-41582007000100003.

Benitez, L. C. Rodrigues, I. C. S. Arge, L. W. P. Ribeiro, M. V. \& Braga, E. J. B. (2011). Análise multivariada da divergência genética de genótipos de arroz sob estresse salino durante a fase vegetativa. Revista Ciência Agronômica, 42(2), 409-416.

Bertran, I. Carvalho, F. I. F. Oliveira, A. C. Vieira, E. A. Hartwig, I. Silva, J. A.G. Shimidt, D. A. M. Valério, I. P. Busato, C. C. \& Ribeiro, G. (2006) Comparação de métodos de agrupamento na representação da distância morfológica entre genótipos de trigo. Revista Brasileira Agrociência, 12(3), 279-286. https://doi.org/10.18539/CAST.V12I3.4554.

Botstein, D. White, R. L. \& Skolmick, H. (1980). Construction of a genetic linkage map in man using restriction fragment length polymorphisn. American Journal of Human Genetics, 32(3), 314-331.

Boza, E. J. Irish, B. M. Meerow, A. W. Tondo, C. L. Rodriguez, O. A. Ventura-López, M. Gomez, J. A. Moore, J. M. Zhang, D. Motamayor, J. C. \& Schnell, R. J. (2013). Genetic diversity, conservation, and utilization of Theobroma cacao L.: genetic resources in the Dominican Republic. Genetic Resources and Crop Evolution 60:605-619. https://doi.org/10.1007/s10722-012-9860-4.

Caixeta, E. T. Oliveira, A. C. B. Brito, G. G. Sakiyama, N. S. (2009) Tipos de marcadores moleculares. In: BORÉM, A.; Caixeta, E. T. Marcadores moleculares. 2.ed. Viçosa: UFV. pp. 11-94.

Cardwel, K. F. Hepperly, P. R. \& Frederikisen, R. A. (1989). Pathotypes of Colletotrichum graminicola and seed transmission of sorghum anthracnose. Plant Disease, 73:255-257.

Casela, C. R. \& Frederiksen, R. A. (1994). Pathogenic variability in monoconidial isolates of the sorghum antracnose fungus Colletotrichum graminicola from single lesions and from monoconidial cultures. Fitopatologia Brasileira, 19(2), 149-153. 
Casela, C. R. Santos, F. G. \& Ferreira, A. S. (2000) Associação de patogenicidade e diversidade fenotípica de Colletotrichum graminicola, agente causal da antracnose em sorgo. Fitopatologia Brasileira, 25(3), 517-521.

Castro, F. M. R.; Potencial Agronômico e Energético de Híbridos de Sorgo Biomassa. Lavras: UFLA, 2014. 80p. Dissertação (Mestrado em Fitotecnia).

Conab - Companhia nacional de abastecimento. Estimativa da produção de grãos no Brasil. http://www.conab.gov.br

Conab - Companhia nacional de abastecimento. Perspectiva para Agropecuária. Volume 3 - Safra 2015/2016. Produtos de Verão.

Costa, R. V. Casela, C. R. Zambolim, L. \& Ferreira, A. S. (2003) A antracnose do sorgo. Fitopatologia brasileira, 28(4),345-354. https://doi.org/10.1590/S0100-41582003000400001.

Cruz, C. D. \& Carneiro, P. C S. (2003) Modelos biométricos aplicados ao melhoramento genético. UFV.

Cruz, C. D. \& Regazzi, A. J. (2001) Modelos biométricos aplicados ao melhoramento genético. UFV.

Cruz, C.D. (2013). GENES - a software package for analysis in experimental statistics and quantitative genetics. Acta Scientiarum, 35(3), 271-276. https://doi.org/10.4025/actasciagron.v35i3.21251.

Evanno, G. Regnaut, S. \& Goudet, J. (2005). Detecting the number of clusters of individuals using the software structure: a simulation study. Molecular Ecology, 14(8), 2611-2620. https://doi.org/10.1111/j.1365-294X.2005.02553.x.

Freeman, S. Katan, T. \& Sabhi, E. (1998). Characterization of Colletotrichum species responsible for anthracnose diseases of various fruits. Plant Disease, 82(6), 596-605. https://doi.org/10.1094/PDIS.1998.82.6.596.

Panizzi, R. C. \& Fernandes, N. G. (1997). Doenças do sorgo. In: Camargo, E. A., Rezende, J. A. M. (Eds.). Manual de Fitopatologia - Doenças das Plantas Cultivadas. São Paulo: Editora Agronômica Ceres. pp. 676-689.

Parreira, D. F. Zambolim, L. Gomes, E. A. Costa, R. V. Silva, D. D. Lana, U. G. P. Neves, W. S. Figueiredo, J. E. F. \& Cota, L. V. (2016). Diversidade genética estimada através de marcadores issr de Colletotrichum graminicola no Brasil. Revista Brasileira de Milho e Sorgo 15(2), 186-194. http://dx.doi.org/10.18512/1980-6477/rbms.v15n2p186-194.

Parreira, D. F. ZAmbolim, L. Gomes, E. A. Costa, R. V. Silva, D. D. Cota, L. V. Lana, U. G. P. \& Silva, E. C. F. Estimativa da Diversidade Genética de Colletotrichum graminicola com Marcadores ISSR. In: XXVIII CONGRESSO NACIONAL DE MILHO E SORGO. Goiânia, 2010. Anais... Goiânia: Associação Brasileira de Milho e Sorgo. 2010. p.731-739.

Pereira, I. S. Silva, D. da D. Casela, C. R. Tardin, F. D. \& ABREU, M. de S. (2011). Resistência de linhagens genitoras e híbridos simples de sorgo a Colletotrichum sublineolum, agente causal da antracnose. Revista Caatinga, 24(2), 46-51.

Perumal, R. Ninmkayala, P. Erattamuthu, S.R. NO, Eun-Gyu.; Reddy, U.K.; Prom, L.K.; Odvody, G.N.; Luster, D.G. \& Magill, C.W. (2008). Simple sequence repeat markers useful for 1-14. http://dx.doi.org/10.1186/1471-2156-9-77.

Pritchard, J. K. \& Wen W. Documentation for structure software: Version 2.1, 2004. http://pritch.bsd. uchicago.edu.

Rohlf, F. J. (1970) Adaptive hierarchical clustering schemes. Systematic Zoology, 19(1), 58-82. https://doi.org/10.1093/sysbio/19.1.58.

Rossi, F. S. Rossi, A. A. B. Dardengo, J. F. E. Brauwers, L. R. Silva, M. L. da. \& Sebbenn, A. M. (2014). Diversidade genética em populações naturais de Mauritia flexuosa L. f. (Arecaceae) com uso de marcadores ISSR. Scientia Florestalis, 42(104), 631-639.

Santos, P. C. M. Lima, W. G. Bezerra, C. S. Michereff, S. J. \& Câmara, M. P. S. (2015) Diversidade genotípica e patogênica de Colletotrichum musae no estado de Pernambuco. Revista Brasileira de Fruticultura 37(2), 355-366. https://doi.org/10.1590/0100-2945-034/14.

Silva, D. D. Casela, C. R. Castro, H. A. Santos, F. G. \& Ferreira, A. S. (2008). Diversidade populacional de Colletotrichum sublineolum, em seis localidades no Brasil. Summa Phytopathologica, 34(2), 149-155. https://doi.org/10.1590/S0100-54052008000200007.

Silva, D. D. Resistência de híbridos de sorgo e diversidade de Colletotrichum sublineolum. Lavras: UFLA, 2009. 175 p. (Tese - Doutorado em Fitopatologia).

Zietkiewicz, E. Rafalski, A. \& Labuda, D. (1994). Genome fingerprinting by simple sequence repeat (SSR)-anchored polymerase chain reaction amplification. Genomics. 20(2), 176-183. https://doi.org/10.1006/geno.1994.1151. 